\title{
The Burden of the Corporate Director Elected Noncumulatively
}

\author{
Hans A. Mattes*
}

\begin{abstract}
The author, a former Assistant Commissioner of the California Department of Corporations, argues that the standard of care provision applicable to corporate directors in the proposed revision of the California Corporations Code affords the opportunity to provide substantial protection of the interests of minority shareholders by taking into account the circumstances of the corporation, and in particular whether the directors were elected by cumulative voting or noncumulatively.
\end{abstract}

Among the many important contributions Professor Richard W. Jennings has rendered to the development of the law of corporations is his part in the continuing administration of the California Corporate Securities Law. He has aided the State Department of Corporations in drafting its laws and regulations. As its legal counsel, he has vindicated the Department's position in litigation concerning basic issues of policy and the boundaries of the state's administrative authority.

In the Western Air Lines case, ${ }^{1}$ Professor Jennings was Of Counsel to the Attorney General, the statutory representative of the Commissioner of Corporations. The court held that under the circumstances presented the elimination of cumulative voting for directors by amendment to the articles of incorporation of the then Delaware corporation was properly considered a sale of securities in California, and was therefore subject to the permit requirement of the California Corporate Securities Law. ${ }^{2}$ The more challenging and enduring issue in the case was the question of California's power to govern the conduct of a corporation chartered by Delaware, but having inost of its business operations, property, principal office, principal bank accounts, employees, and shareholders in California. Such a Delaware corporation, Pro-

* Dr. Jur. 1934, Bonn University; J.D. 1938, University of San Francisco. Engaged in private practice until joining the California Department of Corporations, 1948; Assistant Commissioner of California Department of Corporations, 1965-74; in charge of Office of Policy, California Corporations Commission, 1969-74.

1. Western Air Lines, Inc. v. Sobieski, 191 Cal. App. 2d 399, 12 Cal. Rptr. 719 (2d Dist. 1961).

2. CAI. CORP. CODE $\$ 25009$ (West 1955); id. $\S 25500$, repealed, Ch. $88, \S 1$, [1968] Cal. Stat. 243 (now CAL. CORP. CODE $\$ \$ 25103,25110,25120,25130$ (West Supp. 1974). 
fessor Jennings contended, was a pseudo-foreign corporation, reasonably and constitutionally subject to regulaton by the State of California, and this was the final decision of the court. The decision was an important step in reconciling the technical reach of the laws of the state of incorporation and the realistic concerns of a state in which the predominant effects of the corporate activities are felt. The state's power to regulate pseudo-foreign corporations, though strongly contested before Western Air Lines, has apparently withstood the test of time. The proposed revision ${ }^{3}$ of the California Corporations Code would apply most of its significant provisions to pseudo-foreign corporations as defined in proposed section 2115.4

Under this revision, however, it is doubtful whether mandatory cumulative voting in California corporations or pseudo-foreign corporations will be a part of the future law. ${ }^{5}$ Cumulative voting is the only

3. Assembly Bill 376 was introduced on January 2, 1975 and is presently pending in the California Legislature. The Committee on Corporations of the State Bar of California, chaired by former Corporations Commissioner Anthony R. Pierno, cooperated with the Assembly Select Committee on the Revision of the Corporation's Code, chaired by Assemblyman John T. Knox, to develop the proposed revision [hereinafter referred to as the Draft Code]. Professor Jennings and the author were members of the Committee on Corporations of the State Bar of California [hereinafter referred to as the State Bar Committee].

4. A foreign corporation (other than a foreign association but including a foreign parent corporation even though it does not itself transact intrastate business) is subject to this section if the average of the property factor, the payroll factor and the sales factor (as defined in Sections 25129, 25132 and 25134 of the Revenue and Taxation Code) with respect to it is more than 50 percent during its latest full taxable year and if more than one-half of its outstanding voting securities are held of record by persons having addresses in this state. The property factor, payroll factor and sales factor shall be those used in computing the portion of its income allocable to this state in its income tax return or, with respect to corporations the allocation of whose income is governed by special formulas or which are not required to file separate tax returns, which would have been so used if they were governed by such threefactor formula. The determination of these factors with respect to any parent corporation shall be made on a consolidated basis, including in a unitary computation (after elimination of intercompany transactions) the property, payroll and sales of the parent and all of its subsidiaries in which it owns directly or indirectly more than 50 percent of the outstanding shares entitled to vote for the election of directors, but deducting a percentage of such property, payroll and sales of any subsidiary equal to the percentage minority ownership, if any, in such subsidiary. For the purpose of this subdivision, any securities held to the knowledge of the issuer in the names of broker-dealers or nominees for broker-dealers shall not be considered outstanding.

Draft Code, supra note $3, \S 2115$ (a). Section $2115(\mathrm{e})$ provides another exception for foreign corporations with outstanding securities listed on a national securities exchange certified by the Commissioner of Corporations under section 25100(0) of the Corporations Code, CaI. Corp. Code $\$ 25100$ (o) (West Supp. 1974).

5. Unless otherwise provided in the articles, every shareholder complying with subdivision (b) and entitled to vote at any election of directors may cumulate his votes and give one candidate a number of votes equal to the number of directors to be elected multiplied by the number of votes to which his shares are entitled, or distribute his votes on the same principle among as many candidates as he thinks fit.

Draft Code, supra note $3, \S 708$ (a) (emphasis added). 
procedure for minority shareholders to assure themselves of representation on the board of directors. ${ }^{6}$ It was required of California corporations by the California Constitution until the repeal of article XII, section 12 , in $1930,{ }^{7}$ and is still required under current California corporation law. ${ }^{8}$ While the Western Air Lines decision temporarily encouraged the Commissioner to urge cumulative voting on pseudoforeign corporations, ${ }^{9}$ this requirement was increasingly subjected to multifarious exceptions and was ultimately abandoned. ${ }^{10}$ The Draft Code $^{11}$ would make cumulative voting optional in California corporations and, of course, in pseudo-foreign corporations as well. ${ }^{12}$

It is suggested that one might well accede to this position, considering that the value of cumulative voting as a safeguard of ininority rights probably has been overestimated and that, as will appear, the absence of cumulative voting is compensated by an increased ineasure of responsibility placed on the directors noncumulatively elected. Board presence, the "listening post" demanded by the protagomists of cumulative voting, does not protect minority shareholders against adverse action of a controlling faction in executive committee, in formal board session pursuant to programs previously agreed upon infornially, or for that matter, agaimst the unfavorable mipact of any transaction definitively favored by a majority of the board. After all is said and done, the best protection for minority shareholders is their ability to expect and rely upon faithful and responsible management. An important element in the law desigued to give assurance of such management is the law which defines the duties of the directors of the corporation and imposes civil liability for disregard of those duties. In this respect it is well established that the extent and quality of the directors' duties to the corporation are "to be determined in view of all the circumstances." 13 The director must exercise "such diligence and supervision as the situation and the nature of the busmess requires." 14 It has been

6. N. LATTIN, LATTIN ON CoRporations $\$ 91$ (2d ed. 1971).

7. The repeal was passed in the general election of Nov. 4, 1930. See [1931] Cal. Stat. 83.

8. Cal. Corr. Code $\$ 2235$ (West 1955).

9. Prior to Western Air Lines, the Commissioner of Corporations did not generally insist on cumulative voting in foreign corporations. In that case he justified the requirement on the narrow ground that the shareholders had been granted the right in the articles of incorporation when the company, originally formed in California, was reincorporated in Delaware. The right of minority representation on the board was to be eliminated under circumstances indicating an unfair plan to immobilize and silence minority dissent.

10. Cf. 1 H. Marsh \& R. Volk, Practice Under the California Securities Laws $\$ 7.06[1]-[3]$ (1974).

11. See note 3 supra.

12. See note 5 supra.

13. Briggs v. Spaulding, 141 U.S. 132, 147 (1891).

14. Id. at 170 (Harlan, J., dissenting). 
said that "whether or not a director has discharged his duty . . . depends upon the facts and circumstances of a particular case, the kind of corporation involved," and other factors. ${ }^{15}$ Thus the director's burden is acknowledged to be " a relative concept, depending on the kind of corporation involved, the particular circumstances and the corporate role of the director."18 For example, in a New York case "the fact that the board delegated certain responsibilities to defendants . . . as an Executive or Advisory Committee, and they acted as such" led the court to conclude that "the diligence required of them was greater and the liability stricter," because "[c]are and skill in management are relative concepts depending not only on the type of corporation, . . . but also the corporate role of the directors." ${ }^{17}$

The principle underlying these decisions leads to an important distinction regarding the duties of the directors depending on whether the corporation allows or disallows cumulative voting. A board elected by cumulative voting and consequently composed of minority as well as majority representatives qualifies as the alter ego of all of the shareholders, except of course in transactions where the interests of the majority and minority shareholders are in conflict. In those situations the directors are fiduciaries of the minority. ${ }^{18}$ Aside from this exception, however, a board elected by cumulative voting and thus representative of all the shareholders may ordinarily be deemed to have done an adequate job if it exercises reasonable care in the selection of the managing officers and permits them to operate the busmess under reasonable supervision until circumstances come to light indicating that something is amiss. ${ }^{18}$

A board elected in its entirety by the controlling shareholders without the concurrence of the minority or in opposition to them is a different animal. It certainly is not the alter ego of the minority. On the contrary, it is entrusted with the handling of the corporate property, including the minority's interests therein, without the minority's consent. Such a board, being a trust of its own creation, ${ }^{20}$ should be held to strict accountability. Elected entirely by the majority, yet presuming to act on behalf of the minority shareholders as well, it may in all fairness be expected to exercise the utmost good faith and the highest

15. Litwin v. Allen, 25 N.Y.S.2d 667, 678 (Sup. Ct. 1940).

16. Hoffman, The Status of Shareholders and Directors Under New York's Business Corporation Law: A Comparative View, 11 Buffalo L. REv. 496, 549 (1962).

17. Syracuse Television, Inc. v. Channel 9, Syracuse, Inc., 51 Misc. 2d 188, $196-$ 97, 273 N.Y.S.2d 16, 27 (Sup. Ct. 1966), citing Hoffman, supra note 16. See also Kavanaugh v. Gould, 147 App. Div. 281, 290, 131 N.Y.S. 1059, 1065 (1911).

18. Jones v. H. F. Ahmanson \& Co., 1 Cal. 3d 93, 460 P.2d 464, 81 Cal, Rptr. 592 (1969).

19. See generally, N. LATTIN, supra note $6, \S 78$.

20. Cf. Jones v. Green, 41 N.M. 46, 63 P.2d 1042 (1936). 
degree of care and circumspection with regard to the business and property of the corporation, much as professional trustees who "seek this character of business." 21 Fairminded directors, aware that they have attained power to dispose of the minority's property interests against the will of the minority will normally be sensitive to the heavy moral obligation thus assumed. They will not quarrel with the law if it recognizes that obligation. ${ }^{22}$

It is difficult to see a difference in this regard between directors who are also salaried officers of the corporation and so-called "outside directors" who make their living in another industry or profession in which they have prominence and expertise. The director's burden is assumed voluntarily by insiders and outsiders alike, and in doing so each naturally is motivated by his own self-interest. It is true that outside directors normally render service not so much because they desire the monetary consideration for attending meetings, as because of other benefits which accrue as a result of their directorships. There is still truth in the words of (later Justice) Louis D. Brandeis:

Every one should know that the denial of minority representation on boards of directors has resulted in the domination of most corporations by one or two men; and in practically banishing all criticism of the dominant power. And even where the board is not so dominated, there is too often that "harmonious cooperation" among directors which secures for each, in his own line, a due share of the corporation's favors. ${ }^{28}$

In fairness, all of the directors should bear a share of the responsibility which goes with the prerogatives of the office.

The Draft Code deals with the directors' duties in section 309.24

21. In re Clark, 136 Misc. 881, 889, 242 N.Y.S. 210, 220 (Sur. Ct. 1930), rev'd on other grounds, 257 N.Y. 132, 177 N.E. 397 (1931). Cf. Union Commerce Bank v. Kusse, 21 Ohio Misc. 217, 251 N.E.2d 884 (C.P. 1969); In re Sullenger's Estate, 2 Ariz. App. 326, 408 P.2d 846 (1965). See G. BogerT, Trusts AND TRUSTEEs $\$ 541$ (2d ed. 1960).

22. The German Civil Code expressly recognizes the special burden of one undertaking to handle the affairs of another who has not appointed him to do so ("Geschäftsfuihrung ohne Auftrag"). While under general principles an agent is responsible only for good faith performance, BGB \& 242 (C.H. Beck 1971), a person acting for another without appointment to do so is under a duty to conform to the concerns of the principal and is liable for his failure in this regard even if his performance is otherwise faultless, id. $\$ \S 677,678$.

23. L. Brandeis, Other People's Money: ANd How the Bankers Use IT 58 (1932).

24. A director shall perforn his duties, including his duties as a member of any committee of the board upon which he may serve, in good faith, in a manner he believes to be in the best interests of the corporation and with such care, including reasonable inquiry, as an ordinarily prudent person in a like position would use under similar circumstances.

(b) In performing his duties, a director shall be entitled to rely on information, opinions, reports or statements, including financial statements and 
It recognizes the greater burden of the director noncumulatively elected. The legislature, of course, cannot be expected to specify with exactitude the detail of responsibility assumed by a board of directors; however, the Draft Code states the principle and thus sets the tone which will govern judicial interpretation of that principle. The basic standard set forth in section 309(a) calls for "good faith" and "such care . . . as an ordinarily prudent person in a like position would use under similar circumstances." This formula calls for more than "good faith" and the "care [of] an ordinarily prudent person." The additional words, "in a like position . . . under similar circumstances" are most significant. With regard to directors of a corporation which has dispensed with cumulative voting, these words call for the greater measure of care, the stricter accountability, apphicable to a person who on his own behalf, or on behalf of his constituency, has assumed responsibility for the property and affairs of another who has not consented to his stewardship. ${ }^{25}$ To be sure, the words also recognize that the nature and extent of oversight required and the measure of responsibility imposed may vary depending on other factors such as the magnitude and complexity of the transaction, the size and financial resources of the corporation, the suddenness with which the problem is presented, and the special background and qualification of a particular director to deal with the problen1. ${ }^{26}$ A director lacking business experience or particular expertise still would be bound to use the common sense, practical wisdom, and informed judgment of an ordinarily prudent person. However, being charged with the supervision of a business conducted for profit, any director may be expected to take normal business risks. He cannot be faulted solely for having done so, regardless of the outcome. ${ }^{27}$

other financial data, in each case prepared or presented by:

(1) One or more officers or employees of the corporation whom the director believes to be reliable and competent in the matters presented,

(2) Counsel, public accountants or other persons as to matters which the director believes to be within such person's professional or expert competence, or

(3) A committee of the board upon which he does not serve, as to matters within its designated authority, which committee the director believes to merit confidence,

so long as, $\mathrm{m}$ any such case, he acts in good faith, after reasonable inquiry when the need therefor is indicated by the circumstances and without knowledge that would cause such reliance to be unwarranted.

(c) A person who performs his duties in accordance with subdivisions (a)

and (b) shall have no liability based upon any alleged failure to discharge his obligations as a director.

Draft Code, supra note 3, § 309 .

25. See text accompanying notes 13-17, 20-22 supra.

26. Hughes v. Hughes Coal Co., 11 Misc. 2d 680, 685, 175 N.Y.S.2d 478, 484 (1957); Litwin v. Allen, 25 N.Y.S.2d 667, 678 (Sup. Ct. 1940).

27. See ABA-ALI Model Bus. Corp. ACt $\$ 35$, Comment (rev. 1974) (Adden$\operatorname{dum} B)$. 
Section 309(b) of the Draft Code furnishes an additional lead to the proper definition of the director's burden. The section states that the director is under a duty of "reasonable inquiry." This duty corresponds to the duty of "reasonable investigation" imposed on directors and others by section 11(b)(3)(A) of the Securities Act of $1933^{28}$ with respect to the nontechnical portions of a registration statement. Section 11(c) of that $\mathrm{Act}^{28}$ is authority for the proposition that in relation to strangers purchasing securities of the corporation, the standard of reasonableness is that required of a prudent man in the management of his own property. ${ }^{30}$ In relation to minority shareholders of a corporation which has dispensed with cumulative voting, an even higher duty of inquiry would appear to be "reasonable" under Section 309(b) of the Draft Code.

Failing in his duty of inquiry, the director cannot excuse himself by saying that he did not know or that he relied on what others did or told him. Even though the section enumerates the sources of information on which a director inay in good faith rely in forming his judgment, it expressly conditions his right of rehance by repeating the requirement of reasonable inquiry. It says that to justify any rehance on others, the director first must have inade "reasonable inquiry when the need therefor is indicated by the circumstances," and he must have acted "without knowledge that would cause such reliance to be unwarranted." The "circumstances" indicating the need for inquiry, to which reference is thus made should, of course, include the fact that the director is one elected without the opportumity for cumulative voting, thereby commending the minority shareholders to his special vigilance.

Moreover, rehance on the enumerated sources of information is permitted by section $309(\mathrm{~b})$ only if the director reasonably believes these sources to be "reliable and competent in the matters presented." This language is borrowed froin the Model Business Corporation Act, ${ }^{31}$

\author{
28. 15 U.S.C. $\S 77 \mathrm{k}(\mathrm{b})(3)(\mathrm{A})(1971)$. \\ 29. Id. $\$ 77 \mathrm{k}(\mathrm{c})$. \\ 30. Escott v. Barchris Constr. Co., 283 F. Supp. 643 (1968).
}

31. ABA-ALI MOdel Bus. CORP. ACT $\$ 35$ (rev. 1974) (Addendum B).

In performing his duties, a director shall be entitled to rely on information, opinions, reports or statements, including financial statements and other financial data, in each case prepared or presented by:

(a) one or more officers or employees of the corporation whom the director reasonably believes to be reliable and competent in the matters presented,

(b) counsel, public accountants or other persons as to matters which the director reasonably believes to be within such person's professional or expert competence, or

(c) a committee of the board upon which he does not serve, duly designated in accordance with a provision of the articles of incorporation or the by-laws, as to matters within its designated authority, which commit- 
although the Draft Code omits the word "reasonably" preceding "believes." The arguments in favor of this deletion, which were advanced in the State Bar Committee meetings, indicate that this action was not taken with the intention of permitting directors to rely on incompetent or unrehable information, but from a conviction that the basic prudent man standard clearly enunciated in section 309 would preclude such reliance. In other words, the director must make a reasonable judgment as to the reliability and competency of the information on which he proposes to rely, and in making this judgment he must act with the care of an ordinarily prudent person "in a like position," giving these words the special connotation which they have in the case of a corporation that has dispensed with cumulative voting.

The assurance of responsible management provided by section 309 is buttressed by suitable provisions in chapter 6 of the Draft Code for actions by shareholders, and in chapter 15 for shareholder inspection of the books of account and records of the corporation. Section 1508, based on section 2240 of the present Corporations Code, ${ }^{82}$ authorizes enforcement action of these shareholder rights by the Attorney General. ${ }^{38}$

Altogether, the careful effort made in the Draft Code to modernize the California corporation law, and especially section 309's recognition of the greater burden on directors noncumulatively elected may be relied upon to maintain between inanagement and investors the balance of authority and interest so essential for a proper functioning of our corporate economy.

tee the director reasonab'y believes to merit confidence,

but he shall not be considered to be acting in good faith if he has knowledge concerning the matter in question that would cause such reliance to be unwarranted.

32. (West 1955).

33. The Attorney General, upon complaint that a corporat:on is failing to comply with the provisions of this chapter or Chapter 6,7 or 16, may in the name of the people of the State of California send to the principal executive off.ce of such corporation not ce of the comp'aint. If the a sswer is not satisfactory, the Attorney General may institute, maintain or intervene in such suits, actions or proceedings of any type in any court or tribu nal of compete.nt jurisdiction or before any administrative age 1 cy for such relief by way of . . . remedies as may be appropriate to protect the rights of shareholders or to undo the consequences of failure to comply with such requilements.

Draft Code, supra note 3, \$1508. 